\title{
Public evaluation of the ethics of tobacco marketing in Indonesia:
}

\section{Symbiotic ethical approach}

\begin{abstract}
Purpose This article aims to explore the public evaluation of the ethics of marketing tobacco in Indonesia through the theoretical lens of normative ethics.

Design The present study adopted a symbiotic ethical approach which combined normative and positive ethical approaches. The data was collected in Yogyakarta, Indonesia, from six focus groups and thirty photo elicitation interviews with a total of 71 participants.

Findings The thematic analysis has identified six main themes, economic contribution of the tobacco industry, harmful nature of tobacco products, tobacco marketing targeting vulnerable groups, covering the danger of smoking, intention and integrity of tobacco marketers and infringement of law and social norms. Adopting the theoretical lens of utilitarianism, deontology, contractarianism and virtue ethics, the analysis illustrates that most participants believed that tobacco marketing practices in Indonesia are unethical.
\end{abstract}

Policy implications The findings of the study were disseminated in a public engagement event to stakeholders in Yogyakarta. The findings influenced the development of No Smoking Area monitoring instrument and the introduction of "Free from Tobacco Advertisement in No Smoking Area” policy in Sleman Regency, Yogyakarta.

Originality Indonesia, with its lenient regulatory environment, provides a unique setting for investigating public evaluation of the ethics of tobacco marketing. This is one of the first studies that investigates public evaluation of tobacco marketing ethics in Indonesia through the theoretical lens of utilitarianism, deontology, virtue ethics and contractarianism.

Keywords: tobacco marketing; normative ethics; symbiotic ethics; Indonesia 1 


\section{Public evaluation of the ethics of tobacco marketing in Indonesia:}

\section{Symbiotic ethical approach}

\section{Introduction}

Due to comprehensive tobacco control policies and campaigns in recent years, global tobacco use has declined significantly from 1.397 billion in 2000 to 1.337 billion in 2018 (World Health Organization [WHO], 2019). However, this has not been the case in Indonesia, where the number of smokers has continued to grow. Indonesia, the fourth most populous country in the world, is also one of the biggest producers of tobacco worldwide (Hirschmann, 2020). Indonesia has the highest number of tobacco users (smoked and smokeless tobacco) in the world amongst males (67.4\%) and the highest percentage of adults exposed to second-hand smoke at home (78.4\%) (World Health Organization [WHO], 2018). Furthermore, as tobacco consumption grows, there is a concerning increase in smoking prevalence amongst adolescents (Prabandari and Dewi, 2016), with the WHO (2018) estimating that $36.2 \%$ of Indonesian male adolescents aged 13-15 years old are tobacco users.

Despite this concerning situation, tobacco control policy in Indonesia remains lenient. While 168 countries around the world have ratified the WHO's Framework Convention of Tobacco Control (FCTC), Indonesia is one of the fifteen countries in the world and the only one in Asia that has not (United Nations, 2020). Although there are restrictions placed on tobacco marketing activities, these are frequently disregarded by the tobacco firms and other stakeholders. This exceptional level of leniency might be due to the fact that the tobacco industry is a major source of tax revenue for the government in Indonesia, which allows it 
considerable political and financial influence in the country (Gunawan, 2018). Stricter tobacco control policy was seen to be detrimental to the industry, especially for the farmers and other associated tobacco workers (Jefriando, 2019). In January 2020 Indonesia has increased the excise tobacco tax from $10.04 \%$ to $23 \%$ and the retail price by $35 \%$ (Silaen, 2019). This resulted in approximately $49.50 \%$ excise tax share in the final retail price (Tobacco Atlas, 2020). However, the tobacco tax excise in Indonesia is still considerably lower in comparison to the WHO's (2020) recommendation of $70 \%$ excise tax share in final retail price.

As tobacco marketing ethics study conducted in a country with lenient tobacco control policies is rare, in this study we aim to explore how the Indonesian public evaluate the ethics of tobacco marketing through the theoretical lens of normative ethics. This qualitative study adopts a symbiotic ethical approach which combines both empirical data and normative ethical philosophies of utilitarianism, deontology, virtue ethics and contractarianism. Therefore, the main research question of this study is "How do the Indonesian public evaluate the ethics of tobacco marketing practices through the theoretical lens of normative ethics?". To answer the research question, we conducted 30 photo-elicitation interviews and six focus groups with 41 participants in Yogyakarta, Indonesia.

This article contributes to the business and marketing ethics literature in several ways. Firstly, this is one of the first studies that explores the ethics of tobacco marketing in Indonesia, a country with lenient tobacco control policy. By understanding how the public evaluate the ethics of tobacco marketing practices, we can propose stricter tobacco control policies that comply with normative ethics. In particular, the findings of this study have influenced the 
development of No Smoking Area monitoring instrument and introduction of "Free from Tobacco Advertisement in No Smoking Area” policy in Sleman Regency, Yogyakarta.

Secondly, this article employs a symbiotic ethical approach that combines normative ethics and empirical qualitative study. Qualitative techniques such as in-depth interviews and focus groups are not frequently adopted in the business and marketing ethics research (Brand, 2009). Researchers (Brand, 2009; Hiller, 2010; Reinecke et al., 2016) have called for a greater diversity in the methodology adopted in the business and marketing ethics field. Qualitative methodology may enhance the potential of developing a stronger and richer empirical-based-theory and enable participants to express their perceptions in their own words, and allow themes to be developed for further quantitative testing (Brand and Slater, 2003). Furthermore, "qualitative methods are well poised to understand and explain complex and messy ethical phenomena" (Reinecke et al., 2016, p. xiii).

Thirdly, while studies in business and marketing ethics have generally focused on managers who make business decisions, this article contributes to the literature by exploring how the Indonesian public, who are affected by these decisions, evaluate the ethics of tobacco marketing practices. Furthermore, whilst past studies of tobacco marketing ethics were conducted in countries with strict tobacco control policies (Dewhirst et al., 2016; Morton and Greenland, 2018; Sundaram and Mitra, 2007), this article contributes to the existing literature by revealing how people from a country with lenient tobacco control policies, evaluate the ethics of tobacco marketing through the theoretical lens of utilitarianism, deontology, virtue ethics and contractarianism. 
The article begins with a literature review of normative ethics (utilitarianism, deontology, virtue ethics and contractarianism) and tobacco marketing context. The research methods section describes the study participants, the methods and data analysis. The findings and discussion section discuss the findings through the theoretical lens of normative ethics. The conclusions are followed by policy implications, limitations and future research.

\section{Literature review}

This literature review will discuss the concept of marketing ethics and its different approaches (normative, positive and symbiotic). This is followed by the discussion of normative ethics philosophies (utilitarianism, deontology, virtue ethics and contractarianism) in the context of tobacco marketing.

\subsection{Marketing ethics approaches}

Marketing ethics can be defined as "the systematic study of how moral standards are applied to marketing decisions, behaviors and institutions" (Murphy et al., 2017, p. 5). Individual ethical choices and decision making can be evaluated by utilising normative (prescriptive) and positive (descriptive) approaches. Normative ethics, which is based on philosophy, focuses on "justifying why a particular ethical standard might apply to a given practice and articulating the reasons for upholding such an ideal" (Laczniak \& Murphy, 2019, p.401). This approach produces ethical standards for marketers to define what is right and what is wrong (Chonko and Hunt, 2000; Laczniak and Murphy, 2006). Positive ethics, which is often empirical and based on social science, "describes what actually seems to occur in morally charged situations [often] based on observation or data" (Laczniak \& Murphy, 2019, p.401). The positive ethics focuses on how individuals make ethical choices instead of how they should make them. It "aims to describe, explain, understand, and possibly predict ethically 5 
relevant marketing activities, processes, and phenomena" (Nill \& Schibrowsky, 2007, pp.258-259).

Whilst a number of marketing ethics studies adopt either of the above approaches, Schleidgen, Jungert and Bauer (2010) suggest a collaboration between normative and positive approaches, known as a symbiotic approach (Weaver and Trevino, 1994). Symbiotic approach allows both previous approaches to interact, positive approach collects and evaluates factual phenomenon, and normative approach provides principles to evaluate the phenomenon. Symbiotic approach enables researchers to evaluate whether the investigated social phenomenon is in accordance with the underlying norms (Frith, 2012). If the norms are not applied, further steps can be recommended or undertaken to implement these norms, or new ethical problems and debates may emerge from the investigated phenomenon. Spence and Rutherfoord (2003) add that the role of moral philosophies in business ethics could be enhanced significantly by its application to empirical evidence. Adopting a symbiotic approach, this study will use the theoretical lens of normative ethics of utilitarianism, deontology, virtue ethics and contractarianism to explore how the Indonesian public evaluate the ethics of tobacco marketing ethics.

\subsection{Normative ethics in the context of tobacco marketing}

The tobacco industry provides a unique setting to study the ethics of marketing practices. Whilst the industry is legal, tobacco marketing practices have long been recognised to have a significant influence on tobacco use and addiction. This is because the content and quantity of tobacco marketing aim to promote experimentation with smoking, increase tobacco consumption, discourage quitting and encourage relapse (Forsyth et al., 2013; Henriksen, 2012; Soneji et al., 2014). Evidence of the impact of tobacco marketing on smoking 
prevalence and the initiation of the FCTC have inspired the majority of countries in the world to adopt stricter tobacco control policy (Henriksen, 2012). Nevertheless, the Indonesian government hesitates to implement more rigorous tobacco control policy because of their dependency on the industry. Consequently, tobacco companies in Indonesia could implement marketing activities, from advertising, sales promotion, sponsorships to CSR activities, with little restrictions. Most studies on the ethical dilemmas of marketing tobacco products, were conducted in countries that apply rigorous tobacco control policies (Delpo, 1999; Dewhirst et al., 2016; Palazzo and Richter, 2005; Vermillion et al., 2002). A study in a country that does not have or apply rigorous tobacco marketing regulations, such as Indonesia, may reveal different contextual dilemmas about the ethics of tobacco marketing. In this section we will discuss normative ethics philosophies and their implications on tobacco marketing practices.

From the normative perspective, ethical marketing can be defined as "the practices that emphasize transparent, trustworthy, and responsible personal and/or organizational marketing policies and actions that exhibit integrity as well as fairness to consumers and other stakeholders (Murphy, Laczniak, \& Harris, 2017, p.5). The normative analysis of ethical substances of marketing practice can be evaluated based on four main components, namely the outcomes, action, intention and agreement with convention, or any combination thereof. These components are portrayed in four major strands of normative ethics, namely utilitarianism (ends), deontology (means), virtue ethics (motives) and contractarianism (convention).

\subsubsection{Utilitarianism}

Utilitarianism or consequentialist is a teleological approach introduced by Jeremy Bentham (1748-1832) and is traditionally applied to economics or legal debates and provides a 
functional approach to the ethics of marketing practices (Laczniak and Murphy, 2019). Utilitarianism puts forward the claim that "ethical decisions should maximise benefits for society and minimize harms. What matters is the net balance of good consequences over bad for society overall” (Treviño \& Nelson, 2011, p.40). As utilitarianism focuses on outcomes (Chakrabarty and Bass, 2015), the best ethical decision will be the one that produces the greatest net benefits for society and the worst ethical decision will be the one that produces the greatest net harms for society. In other words, utilitarianism aims to achieve 'the greater good'. Utilitarian philosophy implies that individuals can pursue their personal goals and interests, as long as they do not harm other people (Martin et al., 2016). Past studies have proposed that in controversial industries, like tobacco and alcohol, firms should aim to both minimise harm and maximise positive outcomes (Lindorff et al. 2012; Treviño and Nelson 2011). From the utilitarian perspective, the tobacco industry may benefit the society due to its economic contribution. For instance, stricter regulations on tobacco marketing may harm the employment of almost 2.5 million Indonesian citizens who work in the tobacco industry (World Bank Group, 2018). The utilitarian argument may imply that the cessation of tobacco marketing would damage the country's economy, and therefore, the standard of living of the entire population, because of its dependency on the tobacco industry.

The utilitarian theory has been popular in business and marketing literature because of its utility principle. However, it requires the identification of possible stakeholders who are involved in a particular situation, as well as their alternative actions and potential consequences (Treviño and Nelson, 2011). Therefore, the drawback of this approach is that whilst a decision may bring benefit to a particular stakeholder group, it may harm another stakeholder group (Gustafson, 2013). Furthermore, it may not be easy to gather all the relevant information prior to making a decision and to foresee all potential consequences. In 
the context of the tobacco industry, it is noted that the benefits and profits received by tobacco farmers and factory workers are significantly lower than those received by the top management and owners of tobacco corporations (Chamim et al., 2011).

\subsubsection{Deontology}

Rooted in the work of Immanuel Kant (1724-1804) deontologists believe that the end result of marketing practices, no matter how ethical they may seem, do not justify the use of unethical means. For deontologists, "ethics is grounded in notions of duty and it follows from this that some acts are morally obligatory, regardless of their consequences" (Somerville \& Wood, 2008, p.146). Therefore, it focuses on "the rightness of action, that is, on whether and to what extent a decision conforms to sound moral principles" (Garcia-Ruiz \& RodriguezLluesma, 2014, p.511). The deontologist's position is about doing what is right, with individual well-being as the most important element of every decision (Schlegelmilch et al., 2009). Deontologists argue that certain moral principles - known as natural law, such as honesty, promise keeping, fairness, loyalty, rights (to safety, justice, etc.), responsibility, compassion, respect and loyalty - are binding, regardless of the consequences of the actions (Treviño and Nelson, 2011). Deontology holds that an action is ethical if it is suitable to become a universal law (Ferrell et al., 2015). Products that are inherently dangerous, like tobacco, can only pass the first ethical evaluation if adequate warning is provided (Delpo, 1999). Therefore, tobacco advertisements that exaggerate the emotional benefits of smoking but cover up the products' well-known danger to health could be perceived the act of deception, and therefore, does not comply with the deontology principle.

Unlike the utilitarian view, deontologists argue that certain (harmful) actions should not be undertaken, even to maximise utility. Moreover, it also emphasises that certain actions are 
inherently right and the determination of this rightness focuses on the individual actors, not on society (Ferrell et al., 2015). The deontologists believe that protecting human well-being is a fundamental societal value. Therefore, if there is indication that certain products or actions could harm societies, they should be stopped to prevent the harm (Martin et al., 2016). Nicotine, the most active ingredient in tobacco, has been found to be physiologically and psychologically addictive, in a similar way to heroin and cocaine. Due to this addictive agent, most smokers become strongly dependent on nicotine and find it difficult to quit smoking (National Institute on Drug Abuse [NIDA], 2020). As tobacco is a harmful product, deontologists may perceive marketing activities which encourages the use of tobacco are unethical.

\subsubsection{Virtue ethics}

Virtue ethics is a normative approach concerned with the overall virtue and moral character of actors (Chun, 2019; Shanahan and Hopkins, 2019). It implies that ethical decision making is more than an analytical and rational matter as "it takes a virtuous people to make right decisions" (Williams and Murphy, 1990, p.24). Despite any pressures, virtuous organisations will adhere to certain values and commitments (Chun, 2019).

In terms of ethical purity, intention is the most difficult to evaluate because it requires an understanding of the internal motivation behind a company's actions or policy (Laczniak \& Murphy, 2006). Virtue ethics argues that a person's character must be justified by a relevant moral community, or a community that holds the person to the highest ethical standards. Therefore, a decision maker must consider the community where he or she operates. Virtue ethics is especially useful for somebody who works within a professional community that has developed high standards of ethical conduct for its community members. Nevertheless, it 
must be remembered that a business belongs to various communities. Solomon (1992, p.146) states that "to see business as a social activity is to see it as a practice that both thrives on competition and presupposes a coherent community of mutually concerned as well as selfinterested citizens". Therefore, an ethical business must pay attention to both business performance and the impact of the business activities on the wider community. One may argue that tobacco marketers have a professional responsibility to generate profit for their companies. Thus, as long as their marketing practice is conducted within the legal requirement, this practice may be deemed acceptable. Nevertheless, the fact that tobacco can harm its users, as well as other people around them, cannot be ignored. Furthermore, virtue ethics emphasises that humans should apply reason to avoid both excess and deficiency in their actions (Murphy, 1999). Based on this view, marketers must conduct their marketing activities with moderation and prudence. Aggressive and deceptive tobacco marketing practices do not comply with the principle of virtue ethics which include integrity, fairness, trust, respect, self-control, truthfulness and empathy (Ferrell et al., 2015; Murphy, 1999)..

\subsubsection{Contractarianism}

Social contract theory is based on the notion that individuals' moral or political obligations depend on a collective contract or agreement about ethical principles that help define the basic structure of society (Bay, 2018). This ethical approach aims to solve ethical dilemmas on the level of social rules and procedures. It implies that "while we cannot reach agreement on actual cases, we can reach agreement on general principles" (Luetge et al., 2016, p.688). The social contract concept was reinvigorated by John Rawls, with his work 'A Theory of Justice' (Rawls, 1971). 
At the heart of Rawlsian philosophy is the social contract account of justice, "justice as fairness". The philosophical position focuses on structuring society based on the equality of opportunity principles, which include maximin, equal liberty and difference principles (Bay, 2018). Maximin principle suggests that decisions must be made based on the least bad of the worst possible outcomes. The equal liberty implies that everyone has equal access to basic liberties. The difference principle signifies that social and economic inequalities should be arranged to bring utmost benefits to the least advantaged in society (Rawls, 2001). The concept of veil of ignorance is also an integral element of the Rawlsian perspective. It suggests that when facing or solving a moral dilemma, individuals must be placed in a situation without knowing who they are in the society (i.e. position, social status, assets, abilities, intelligence, etc.). This principle is based on the belief that individuals cannot be impartial judges when their own interest or individual morality is at stake (Gaus, 2011).

The ethical implications of marketing campaigns directed at well-informed customers are different to those targeted at the vulnerable groups, who may not be able to make wellinformed decisions or understand the persuasiveness of tobacco marketing messages and activities. Tobacco companies tend to design marketing strategies that attract vulnerable groups such as children and people with low-sociodemographic background, by using attractive marketing messages, sales promotional features, sponsorships and CSR activities (Arli et al., 2015; Bialous and Eijk, 2020; Boseley et al., 2018; Tjandra, 2018). These indicate that tobacco marketing activities do not comply with contractarianism philosophy which prioritise the well-being of the vulnerable group.

Another popular strand of contractarianism is the Integrative Social Contract Theory by Dunfee et al. (1999). The theory aims to enhance ethical decision making by considering the 
impact of decisions on relevant communities and the existence of universal moral principles that apply to all cultures and communities. It is based on two main principles, moral free space principle, which is a degree of relativity in developing the rules; and hypernorms principle, which is universal religious, cultural, philosophical and legal norms (Laczniak and Murphy, 2019). This theory also requires individuals to obey micronorms, "communityspecific norms that are consistent with the behavior and beliefs of most individuals in the group and reflect chosen values and preferences" (Levine, 2019, p.395). From the ISCT perspective, tobacco marketing activities that do not comply with both hypernorms and micronorms in the society are considered unethical. For example, despite the adoption of stricter tobacco control policy, evidence also shows that tobacco companies and pro-tobacco activists around the world, often interfere (Glenza, 2017), and do not hesitate to use legal actions against the government and anti-tobacco control activists to hinder the advancement in the tobacco control policies (Cooper, 2015).

Normative ethics is commonly used to better understand and justify ethical decision making process in the context of organisations (Hosmer, 1994). It is rarely used to evaluate the ethical perceptions of the public who is affected by the organisations' decisions. Therefore, this study aims to fill the gap in the existing body of the literature by exploring how the Indonesian public evaluate the ethics of tobacco marketing through the theoretical lens of normative ethics.

\section{Research methods}

This article adopts a qualitative method, which is usually seen as theory elaboration and generation, rather than theory testing (Reinecke et al., 2016). Qualitative methods are useful for evaluating unique questions in business ethics as they enable access and exploration of 13 
participant personal perception and experience in rich and meaningful terms (Crane, 1999). Ethical perception is complex as it is not only about how people perceive particular situations but also their ability to recognise the morally significant elements embodied in situations (VanSandt et al., 2006), and therefore, qualitative research is deemed to be appropriate to capture this complexity.

This study was conducted in Java, the most populous Indonesian island as well as the largest Indonesian producer of cigarettes. More specifically, the study was undertaken in the Special Region of Yogyakarta. The data collection was conducted in eight kelurahan (urban villages) in Yogyakarta. Community leaders from these districts were contacted in advance to help the researchers recruit potential participants. The participant profiles are presented in Table 1 . The sample also covers a variety of backgrounds in terms of sex, age, education/qualification status, marital status, occupation and monthly income. All participants were pre-informed that the research was about how they evaluated the ethics of tobacco marketing activities.

Table 1 Participant profiles

\begin{tabular}{|l|l|l|l|}
\hline \multicolumn{2}{|l|}{ Characteristics } & Focus groups & Interviews \\
\hline \multirow{4}{*}{ Sex } & Male & 27 & 23 \\
\cline { 2 - 4 } & Female & 14 & 7 \\
\hline \multirow{4}{*}{ Marital status } & Single & 20 & 7 \\
\cline { 2 - 5 } & Married & 19 & 20 \\
\cline { 2 - 5 } & Widowed & 2 & 2 \\
\cline { 2 - 5 } & Divorced & 0 & 1 \\
\hline & $18-24$ & 12 & 4 \\
\cline { 2 - 4 } & $25-34$ & 8 & 11 \\
\hline
\end{tabular}




\begin{tabular}{|c|c|c|c|}
\hline \multirow{5}{*}{ Age } & $35-44$ & 5 & 3 \\
\hline & $45-54$ & 3 & 8 \\
\hline & $55-64$ & 4 & 2 \\
\hline & $65+$ & 5 & 1 \\
\hline & No answer & 1 & 1 \\
\hline \multirow{6}{*}{ Highest education } & No formal education & 0 & 2 \\
\hline & Elementary school & 0 & 0 \\
\hline & Junior High School & 1 & 1 \\
\hline & Senior High School & 26 & 18 \\
\hline & Bachelor's Degree & 13 & 6 \\
\hline & Master's Degree & 1 & 2 \\
\hline \multirow{6}{*}{ Occupation } & Unemployed & 4 & 1 \\
\hline & Student & 9 & 1 \\
\hline & Civil servant & 1 & 5 \\
\hline & Private sector employee & 9 & 10 \\
\hline & Self-employed & 10 & 10 \\
\hline & Retired & 8 & 3 \\
\hline \multirow{6}{*}{ Income } & Below IDR 1,000,000 & 13 & 1 \\
\hline & IDR $1,000,000-2,499,999$ & 15 & 8 \\
\hline & IDR 2,500,000 - 4,999,999 & 7 & 14 \\
\hline & IDR 5,000,000 - 9,999,999 & 1 & 7 \\
\hline & Above $10,000,000$ & 1 & 0 \\
\hline & No answer & 4 & 1 \\
\hline Smoking status & Smoker & 20 & 15 \\
\hline
\end{tabular}




\begin{tabular}{|l|l|l|l|}
\hline & Non-smoker & 21 & 15 \\
\hline
\end{tabular}

This study adopted both photo elicitation interviews and focus groups. This multi-method approach does not only enhances the richness of the data but also corroborates findings (Lambert and Loiselle, 2008). Both methods can provide complimentary views and contributes to a more comprehensive understanding. Whilst photo elicitation interviews can explore personal perceptions and experiences, focus groups can examine public belief and knowledge about a phenomenon (Michel, 1999).

\subsection{Photo-elicitation interviews}

Thirty individual photo-elicitation interviews with 15 smokers and 15 non-smokers were conducted. This was consistent with the recommendation that data saturation can be achieved after 10 to 25 photo-elicitation interviews (Coulter and Zaltman, 1994). "Photo-elicitation is based on the simple idea of inserting a photograph into a research interview" (Harper, 2002, p.13). However, elicitation studies are not only limited to the use of photographs, they can utilise any visual image (Harper, 2002). To provide more flexibility to participants, they were asked to bring between eight to ten images from magazines, newspapers, pieces of artwork, or pictures from the internet or photographs that represent their evaluation of the ethics of tobacco marketing in Indonesia. They were informed that we were interested in their thoughts and feelings and the images should not be the actual tobacco advertisement. As an option, whenever participants could not bring pictures, they selected pictures from an image bank randomly selected from magazines and newspapers prepared by the authors. 
The participants were asked to describe how each picture or image reflected their evaluation of the ethics of tobacco marketing. As the participants spent time thinking about their task and collecting pictures, they came to the interview with a story to tell (Coulter and Zaltman, 1994). The use of images during the interviews were useful to facilitate interview dialogue (Tinkler, 2013). It enabled longer and more comprehensive interviews and at the same time reduced fatigue and repetition associated with conventional interviews (Harper, 2002). Throughout the interviews, the first author probed interesting areas that arose and asked for more elaboration. To consolidate their thoughts, at the end of the interview, the participants were asked to choose (an) image(s) that summarised their overall perceptions of the ethics of tobacco marketing and if there was anything they would like to add but had not been covered in the interview. The average length of the interviews was 75 minutes.

\subsection{Focus groups}

The focus groups were designed in an interactive group setting, which allowed respondents to talk with other group members freely (Krueger and Casey, 2000). The participants have different background in term of age, gender, occupations and interest but must have similarity that becomes the nature of the study (Morgan, 1997). Therefore, whilst the participants have different demographic backgrounds, they were categorised into three groups of smokers and three groups of non-smokers. Three focus groups were considered adequate to uncover all important themes within the data set (Guest et al., 2017). As the preferred number of participant for each focus groups was between six and eight participants (Krueger and Casey, 2000), in this study five groups consisted of seven participants and one group consisted of six participants. The first author moderated the focus groups and was assisted by an experienced note-taker. The participants were asked to discuss how they evaluated the ethics of tobacco 
advertising, promotion and sponsorship (TAPS). The average length of the focus groups was 60 minutes.

\subsection{Data analysis}

All interviews and focus groups were conducted in Indonesian, tape-recorded and transcribed verbatim. The initial data coding and analysis process was undertaken in Indonesian by the first author. All authors are bilingual in Indonesian and English. Quotations that represented key themes were translated into English. To avoid misinterpretation, the English translation were compared with the Indonesian transcription, the quotes were back translated, and the accuracy of the translation was discussed with other authors (Halai, 2007).

After the twentieth interview and fourth focus groups, the first author became aware that data saturation was reached as some categories occurred frequently in the data and that the subsequent interviews yielded fewer new categories and examples (Payne, 2016).

Nevertheless, further interviews and focus groups were undertaken to ensure that identified categories captured and represented all variations in the data (Hawker and Kerr, 2016). The combination of inductive and deductive thematic analysis was adopted to analyse the data (Clarke and Braun, 2016). This means that codes and themes were first generated from the data, focusing on the participant evaluation, at the later stage of data analysis, the theoretical framework of normative ethics was adopted as a lens to interpret the data. The data analysis was conducted with Nvivo software. When analysing the data, the authors followed Clarke and Braun's (2016) thematic analysis process.

The first step was data familiarisation, where the first author read and re-read the data in order to develop a semantic and obvious meaning of the data. In the second step, data coding, 
she was going through the data systematically and developing codes for data segments. When something of interest came up, a decision was made on whether to create a new, or to use an existing code. Each code was discussed with the second and third authors to ensure that the codes evoked meanings of the data segments. The third step was developing themes from the codes. At this stage, the authors focused on a general patterning of meaning and clustered related codes to identify the potential themes.

To ensure a good fit between the data and themes, the themes were checked against all coded data as well as the entire data set. To control the quality, this process was repeated and involved discarding, combining, refining and splitting themes (Terry, 2016). This process resulted in six main themes. Table 2 illustrates various codes that contributed to the development of six main themes discussed in this article.

Table 2 The relationship between codes and themes in the data analysis

\begin{tabular}{|l|l|}
\hline Codes & Themes \\
\hline Cigarette companies have the most money & Economic contribution of the \\
Dependency on the cigarette industry & tobacco industry \\
Employment contribution & \\
\hline Smoking is not good for health & Harmful nature of tobacco \\
Smoking is addictive & products \\
Tegative effects on passive smokers & \\
\hline
\end{tabular}




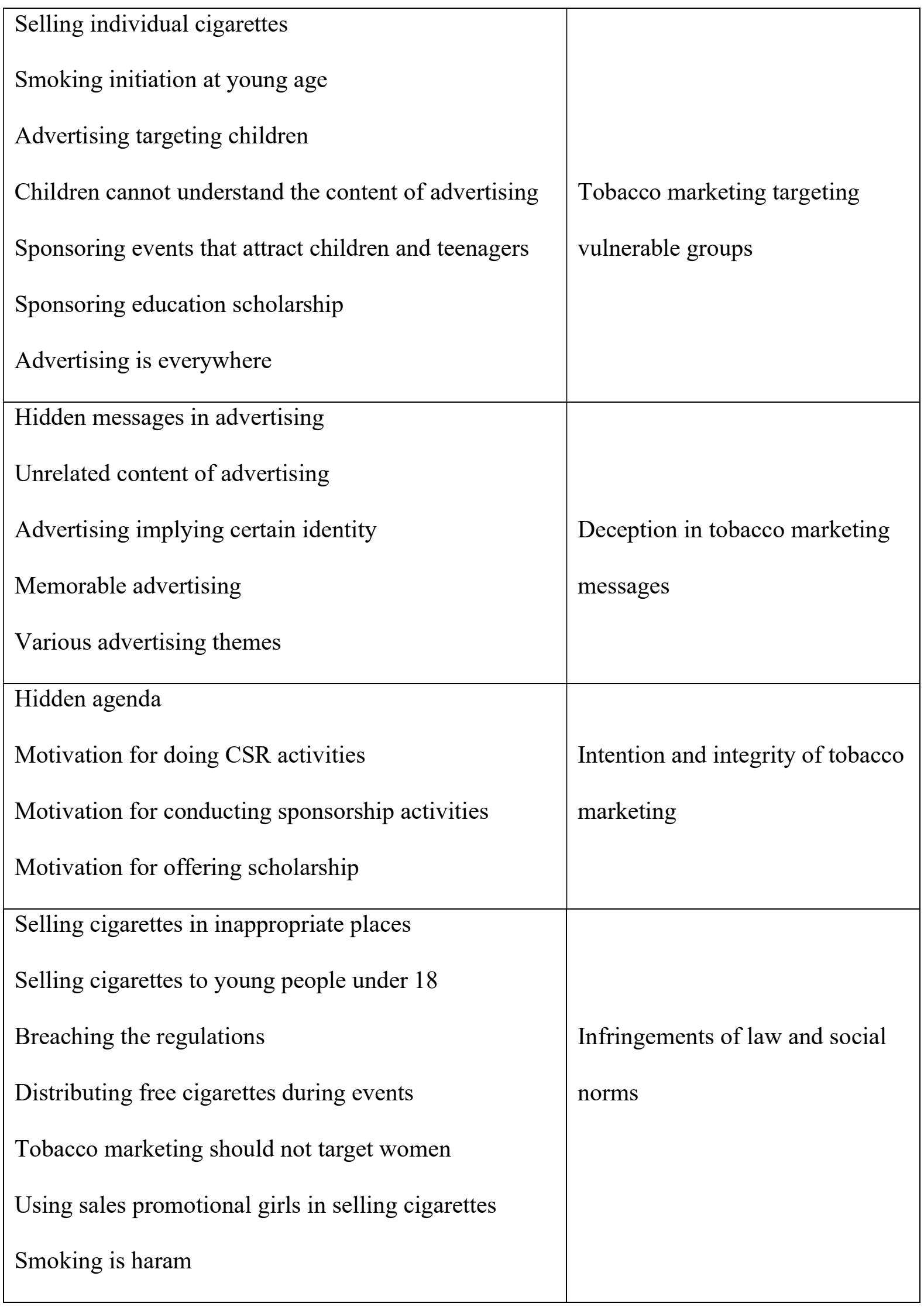


To develop a narrative that illustrates the findings and to refine its focus and scope, a detailed analysis was then undertaken. Once this stage was completed, the authors contextualised the findings using the theoretical lens of utilitarianism, deontology, virtue ethics and contractarianism by weaving the relevant literature into the analysis to support the findings as presented in the following section.

\section{Findings and discussion}

The thematic analyses resulted in six main themes, economic contribution of the tobacco industry, harmful nature of tobacco products, tobacco marketing targeting vulnerable groups, deception in tobacco marketing messages, intention and integrity of tobacco marketers and infringement of law and norms in the society (Figure 1). Adopting the theoretical lens of normative ethics, we discuss how the themes are positioned within the utilitarian, deontology, virtue ethics and contractarianism philosophies. 
Figure 1 Emerging themes

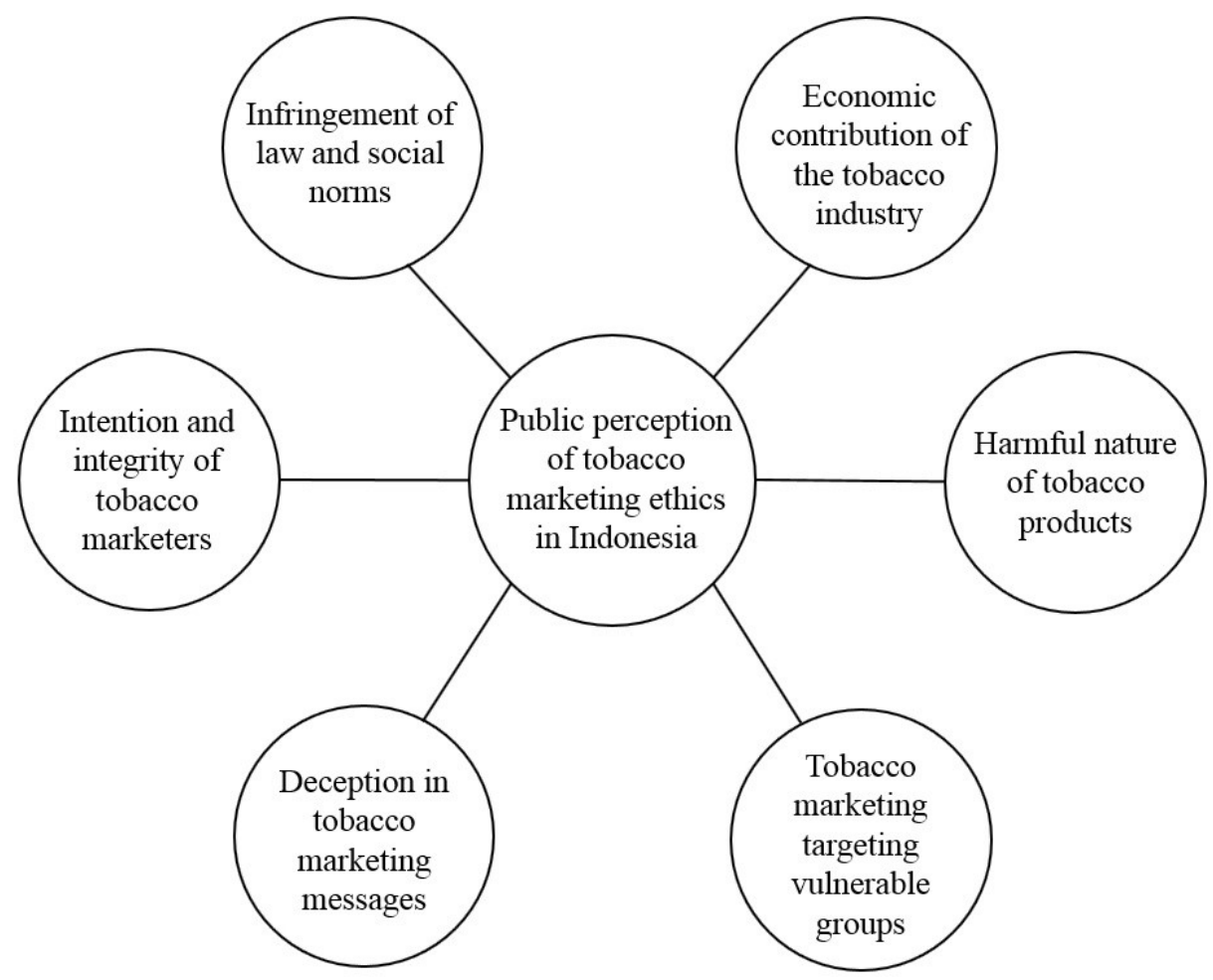

Table 3 illustrates the examples of participant responses for each theme. 
Table 3 Examples of participant responses for each theme

\section{Economic contribution of the tobacco industry}

When discussing tobacco companies, we must not only think about the tax that they generate.

But we must also think about the labour [employment]. For example, if they [tobacco companies] are closed down, it will be difficult. For example, [brand A], employs 10,000 people who have wife and children. We have to think about that. If they want to reduce the number of tobacco companies, the government must come up with a solution. They cannot just close them down without coming up with a solution of new employment (Focus group 1, Non-Smoker D).

In my opinion, it's all about business. I don't think tobacco companies give any concrete contribution. For example, [Brand B], every year they support sport activities but that contribution is only a very small percentage of their income (Focus Group 2, Smoker C).

\section{The harmful nature of tobacco products}

It is unethical for tobacco companies to sponsor sporting events because they are contradictory. Sport is the opposite of smoking. Smoking is unhealthy, whereas sport is healthy, for health (Interview, Non-Smoker 9)

There are events organised by tobacco companies. The purpose of these events is to gather young people. They will say, let's organise dangdutan [Indonesian folk music concerts], we will sponsor you. They may view it to be ethical. But, in my opinion it's unethical because it [smoking] kills. It's like using one bomb to kill many people, do you know what I mean?" (Interview, Non-Smoker 14)

\section{Tobacco marketing targeting vulnerable groups}

If the sponsor is not a tobacco company, it's good. Cigarettes can have negative effects.

Cigarettes can damage the student generation, influence them to smoke. Maybe because they were funded by cigarette companies, they will try cigarettes, and this can damage their 
generation. Those who have achievement potential. The sponsor should have been products other than cigarettes. But, for now, the biggest contributors are still cigarette companies. (Interview, Smoker 12)

Cigarettes should be marketed to those with high incomes. I think it's because those with higher income have better education, so they are aware of the dangers of cigarettes. If they are addicted to cigarettes and become ill, they have a lot of money to cure their illness. (Interview, Non-Smoker 14)

\section{Deception in tobacco marketing messages}

I think all of them [tobacco advertising] are unethical. They are not supposed to advertise but they insist. The advertisements are intended to make people buy cigarettes, but people don't know about the effects [of tobacco] on the environment and the danger of smoking" (Interview, Smoker 13).

When children and teenagers go to concerts, they want to see their idols in the concerts. There was a concert recently, sponsored by [Brand C]. Usually when you buy tickets, you get cigarettes. I think it's unethical. They can sponsor but not giving out cigarettes (Interview, Smoker 3).

\section{Intention and integrity of tobacco marketers}

From the humanitarian perspective, tobacco companies sponsoring charity event is ethical. But, maybe it's a form of hidden promotional activities. So, they are not only giving out help but also advertising their products. It's like killing two birds with one stone (Interview, NonSmoker 2).

Tobacco companies help schools a lot. But is it ethical? I mean, the students are our future. Tobacco is the source of poison. So, it is unethical because tobacco companies have hidden purposes. To make their products famous. If their products are famous, a lot of people will 
like them, idolise them. So, it's all about advancing their products (Interview, Non-Smoker 14).

\section{Infringements of law and social norms}

Cigarettes are associated with pretty women. The ones who promote cigarettes are pretty, like in the advertisements. The sales promotion girls will approach men one by one offering them promotion. If the SPGs are not pretty, the men will not be attracted. When they sell them on streets or villages, it's unethical. People will perceive them as selling their body. Children will see pretty women sell cigarettes (Interview, Smoker 3).

The law is there, but it is not being enforced. So, it means nothing. We can violate the law. If you want to buy cigarettes, you do not need to show your proof of identity. It is written that you must not sell cigarettes to those under 18. It's written that they are only for those aged 18 and above (Focus Group 3, Smoker B)

\subsection{Economic contribution of the tobacco industry}

Most participants commented on the tobacco industry's economic contribution to the country.

The participants' functional approach in evaluating the economic contribution of the tobacco industry reflects the utilitarian perspective which implies that ethical decisions should maximise benefits for society and minimize harms (Treviño and Nelson, 2011). The utilitarian view that concerns the welfare of the many, rather than just the individual (Gustafson, 2013), is also reflected in participants' viewpoint. Some participants were concerned that further restrictions on tobacco marketing and the industry would negatively impact on employment and national income. They suggested that prior to restricting the operation of tobacco companies, government had to provide alternative employment. Several participants also explicated that tobacco companies had financial resources and, at the same time, willingness to donate and sponsor sporting and music events and scholarships. 
Whilst admitting the economic contribution of the tobacco industry, the participants also commented on the distribution of the economic benefits of the tobacco industry. They described the tobacco companies' regulations were not "pro-society". They believed that the contribution of tobacco companies was only a small portion of their overall profit and the biggest beneficiaries of tobacco industry were the owners of the companies, not the society at large, as illustrated by one participant,

If everybody in the world is smoking, I don't think tobacco farmers will become rich. The ones who will be rich are the bosses. Once I went to visit [tobacco brand 3]'s factory in [a city], the cigarette rollers are women. Sometimes when we enjoy cigarettes, we forget that the rollers are housewives who receive very low wages. The bosses will be rich but the farmers and those at the bottom will remain poor" (Focus Group 3, Smoker E).

This viewpoint illustrated that the tobacco industry operations were considered to only benefit a certain group of stakeholders. Therefore, it can be suggested that their operations are against the utilitarian principle which prioritises the greatest net benefits for society (Chakrabarty and Bass, 2015).

\subsection{Harmful nature of tobacco products}

Throughout the study, participants consistently refer to the harmful and addictive nature of tobacco products as a point of reference in evaluating the ethics of tobacco marketing activities. Deontology believes that certain (harmful) actions should not be undertaken, even to maximise utility (Hackley et al., 2008). Most participants recognised the negative impacts of smoking on both active and passive smokers. They believed that smoking was not good for health and could cause various diseases, "From the health perspective, smoking is about 
inhaling poison. Smoking is not good for health, it causes many diseases" (Interview, NonSmoker 2). Some smokers and ex-smokers recognised the addictive nature of smoking and expressed their difficulty of quitting smoking, "Actually, we want to quit smoking, but I don't know what ingredients that they use, so we are addicted" (FG 1, Smoker B). As smoking is harmful, from the deontologist perspective, any activity which encourages smoking can be considered morally wrong (Hackley et al., 2008). In this respect, for deontologists, tobacco marketing is an unethical practice. Because of the unhealthy nature of tobacco products, some participants further suggested that it was unethical for tobacco companies to sponsor sporting events such as badminton, football or volleyball which aimed to promote healthy lifestyles. In addition, the action of tobacco companies selling harmful products to the society is also against the utilitarian principle which implies that one must not harm other people in their pursuit of goals and interests (Martin et al., 2016).

\subsection{Tobacco marketing targeting vulnerable groups}

The wellbeing of vulnerable groups, such as children and teenagers, and those with lowsocioeconomic status, was one of the dominant aspects of the findings. Confirming past studies almost all participants considered children and teenagers to be more vulnerable and less able to understand the persuasive content of cigarette advertising (Braverman and Aarø, 2004; Nicholls and Cullen, 2004). This vulnerability was the underlying basis for the claim that tobacco marketing has directly and indirectly targeted young people, as illustrated by one participant, "Children will not understand hidden messages in the advertisements. These are unethical. Some of them may give positive encouragement in life, but I don't think it's good. In general, the tobacco advertisements are not ethical" (Interview, Non-Smoker 2). 
A number of smokers and non-smokers in the study commented on how tobacco advertising did not influence their intention to smoke but would attract young people. Young people were considered to be susceptible to advertising which emphasised that smoking made someone seem to be grown up, "When seeing a cigarette advertisement with the slogan 'Men have good taste', teenagers in their puberty may think that I want to look like an adult or more masculine, so I will smoke that cigarette" (Focus Group 1, Smoker 1). Despite the regulations restricting tobacco advertising on broadcast media (TV and radio) to between $9.30 \mathrm{pm}$ to 5am, participants were worried that young people could see tobacco advertising on the internet, print media and outdoor.

Tobacco firms were also perceived as using and manipulating sponsorship (e.g. sport, music and education) to gain a positive image among young people.

Tobacco companies sponsoring music concerts attended by young people is unethical. They are very unstable. For me, they have not had a principle that they can sustain. So, they will follow others. Their principle can be shaken. They start with smoking then worse, drugs. The consequences could go anywhere because they are on a slippery slope" (Interview, Smoker 7).

Some participants also highlighted that tobacco marketing should not target low-income groups. Confirming past research, (Truth Initiative, 2018; Wan, 2017), many participants believed that smoking puts them at greater financial risk, and they might not be fully educated about the dangers of smoking. A participant commented, "Smoking is expensive. People can use the money for other things. How much will they spend a month? Morally, cigarettes must not be targeted at low-income people. I mean, they find it difficult to buy food, let alone cigarettes" (Interview, Non-Smoker 8). Finally, participants also suspected the 
intention of selling single cigarettes was to open an opportunity for children, teenagers and people with lower income to purchase cigarettes easily.

The theme of targeting vulnerable group shows that participants emphasised a need for tobacco marketers to uphold a moral responsibility by not marketing tobacco to young people and people with low sociodemographic status. The theme suggests people's suspicion of tobacco firms manipulating the vulnerability of these groups. The participants' views have illustrated that the harmful and addictive nature of tobacco products are not in line with the spirit of deontology and contractarianism which is about doing what is right and prioritising individual well-being in every decision. Furthermore, by conducting marketing activities that are attractive for these vulnerable groups, the tobacco companies' intention is likely to enhance their image amongst these groups. This suspicious motive does not comply with the principle of virtue ethics (Chun, 2019).

\subsection{Deception in tobacco marketing messages}

The findings illustrate that tobacco firms were considered using deceptive messages to market their products by covering up the danger of smoking in their advertisements. Due to this fact, tobacco marketing was perceived as unethical by some participants, with comments including: "Even though there is a warning that smoking kills, tobacco advertisements still show that smoking is safe. I think tobacco advertisements are not entirely ethical. They cover up the real effects of smoking." (Interview, Non-smoker 1). Therefore, it can be suggested that tobacco advertising is not in line with the deontological perspective which is against unethical methods and deception of marketing products (Hackley et al., 2008) 
Tobacco marketers use a variety of aspirational tropes in their advertisements to engage and persuade audiences to smoke, such as enthusiasm, persistence, bravery, enjoyment, masculinity, success, humour, youth, adventure and family. The messages implied in tobacco advertisements attempt to project a positive identity. However, most participants perceived these messages to be untrue and unrealistic.

I think tobacco advertisements look good. But that's it. From the ethical perspective, it's not ethical. They combine bravery and smoking. So, it seems like when you smoke, you will be brave, but in reality it's not like that. So, I don't think it's ethical. A lot of brainwashing, distorting the facts. If you smoke you become brave. In reality, you don’t. (Interview, Non-Smoker 15).

These findings suggest that deception leads to the participants' distrust in tobacco marketing messages as they appear to glamorise the temporary pleasure customers get from smoking but say nothing about the products well-known danger to health. Laczniak and Murphy (2006) further imply that deception in marketing practices also violates the principle of virtue ethics because an efficient marketplace is built upon trust and this characteristic must be nurtured by marketers' honesty.

\subsection{Intention and integrity of tobacco marketers}

In line with the principle of virtue ethics (Laczniak and Murphy, 2006), our finding illustrated that most participants questioned the intention of tobacco companies in conducting their marketing activities, especially through their corporate social responsibilities (CSR) and sponsorship. One participant suggested, "Despite their defence that they made contribution and their action is legal, we need to look at their intention" (Focus Group 2, Smoker D). 
When discussing tobacco companies' effort in helping natural disaster victims, some participants thought the practice was good, but the majority of respondents believed that their intention was actually to promote their brand and therefore, the action was unethical, "Based on law and regulations, tobacco companies can help natural disasters. It's good. But if we look at their intention, it is unethical. They just want to promote their products" (Focus Group 2, Smoker C). A few participants had witnessed a tobacco company set up an emergency camp to help with evacuating volcano explosion victims, but at the same time, also selling cigarettes to the victims. As suggested by (Yoon et al., 2006), whilst tobacco companies believe that CSR activities will help augment any negative image associated with this distribution, it is doubtful that firms are sincere in their motives to better society.

Some participants also believed the hidden purpose of offering education scholarships was to increase the public's sympathy towards tobacco company. This confirms Arli et al.'s (2015) study which suggests that CSR activities enhance Indonesian consumers' positive perceptions of tobacco companies. One participant suggested,

The scholarships for University or high school students are aimed at poor people. So, if they were given money, they might say I was given money, I should use their product. They could be sympathetic [towards tobacco companies]. Or perhaps because their education is limited, they are easily influenced by tobacco companies (Interview, Non-smoker 14).

Similarly, some participants questioned the intention of tobacco companies sponsoring sporting and music events. They believed that the purpose of sponsoring these events was to promote the tobacco brand, "So, if we buy concert tickets, they advertise their cigarettes. We do not realise that the purpose of giving out the cigarettes is to make sure that the brand is recognised” (Focus Group 3, Smoker D). 
From the deontological perspective, the sponsorship and CSR activities of tobacco companies can be seen as fulfilling duties or responsibilities towards relevant stakeholders and society (Chakrabarty and Bass, 2015; Somerville and Wood, 2008). Nevertheless, questions remain as to whether these activities can compensate the detrimental effects of tobacco on the society. Furthermore, participants recognised the contradiction between the unhealthy nature of tobacco and the companies' efforts in sponsoring sporting events; suggesting that they conducted these activities with a hidden agenda. Therefore, the industry's intention in conducting these activities is not purely to become a responsible corporate citizen. Their intention is likely to mask the distribution of their products and enhance their image in the society, and therefore does not comply with the principle of virtue ethics which emphasises the moral character of an organisation to be driving force of their action (Shanahan and Hopkins, 2019).

\subsection{Infringement of law and social norms}

During the research some participants suggested that because tobacco products were legal, tobacco companies should be allowed to conduct their business like other companies, as implied by one participant, "Since cigarette is legal, from the company's point of view it is only ethical if they are allowed to advertise their products" (Focus Group 3, Smoker C). Nevertheless, participants also witnessed tobacco companies infringed the tobacco control regulations in their marketing activities, for example, by distributing free cigarettes during sporting or music events, as illustrated by a participant, "In 2012, I was 16, I was watching concerts with my friends. Two different concerts. Both sponsored by tobacco companies. We bought the ticket for IDR10,000 and got a pack of cigarettes. Not bad.” (Interview, Smoker 9). 
Despite formal regulations prohibiting the selling of cigarettes to anyone under 18 years old, many participants had witnessed many infringements, deliberate or not, of this regulation. Some participants had witnessed cigarettes being sold within a very close proximity to schools as well as inside the schools. Furthermore, they also recognised how tobacco companies were bending the law in some of their tobacco marketing activities. For example, one participant illustrated, "If you look at the law, says tobacco advertisements must not show people smoking. But the pictorial warning on the packaging and the advertisements still shows people smoking” (Focus group2, Smoker A). In marketing, legality must be used as the main measure to evaluate the ethical status of the motive (Hackley et al., 2008). Therefore, the tobacco companies' actions of breaching the law is not in line with both virtue ethics and contractarianism principles (Laczniak and Murphy, 2019).

In addition to obeying the law, the participants also commented that tobacco companies did not respect the norms in the society. For example, many participants believed that tobacco marketing which targeted women was unethical, because it did not align with the Eastern culture. Sales promotion girls selling cigarettes was also considered unethical because they were perceived to use sexual appeal in selling tobacco products. Other participants had also witnessed that tobacco companies disrespected the attempts of creating a free-smoking environment by sending tobacco sales representatives to distribute and sell cigarettes in these areas. Finally, some participants believed that tobacco marketing activities were considered unethical as smoking was categorised as haram (forbidden by Islamic law) by Muhammadiyah, the second largest Muslim organisation in Indonesia. The evidence of this study suggested that tobacco marketers did not hesitate to disrespect the norms in the society in order to market their products, and therefore they did not comply with the principle of 
contractarianism (Levine, 2019). Their actions were also against the virtue ethics principle which requires individuals to consider the moral standards within the community where they operate when making decisions (Treviño and Nelson, 2011) as well as avoid both excess and deficiency in their actions (Murphy, 1999).

Table 4 illustrates the summary of participant evaluation of the ethics of tobacco marketing in Indonesia through the theoretical lens of normative ethics. The table shows that each theme can be positioned within at least one of ethical philosophies of utilitarianism, deontology, virtue ethics and contractarianism. Based on this discussion, it can be suggested that from the normative ethics perspective, tobacco marketing practices in Indonesia are considered unethical. 
Table 4 The mapping of the public ethical evaluation of tobacco marketing in Indonesia through the theoretical lens of normative ethics

\begin{tabular}{|c|c|c|c|c|}
\hline \multirow{2}{*}{ Themes } & \multicolumn{4}{|c|}{ Normative ethics } \\
\hline & Utilitarianism & Deontology & Virtue ethics & Contractarianism \\
\hline $\begin{array}{l}\text { Economic } \\
\text { contribution } \\
\text { of the } \\
\text { tobacco } \\
\text { industry }\end{array}$ & 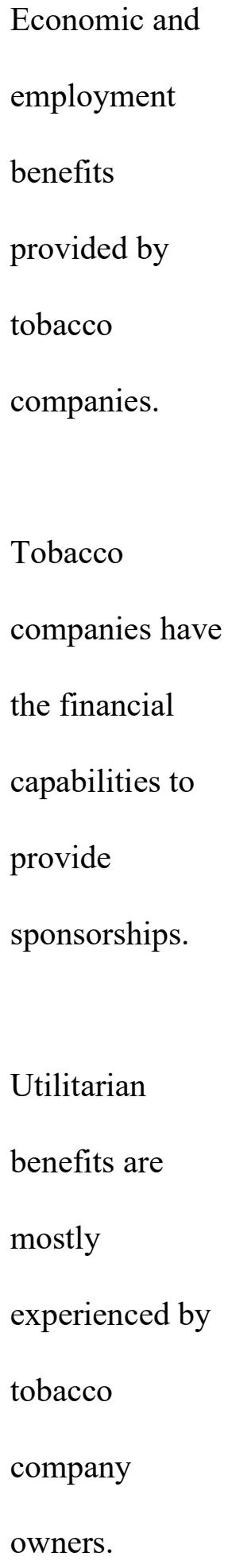 & --- & --- & --- \\
\hline
\end{tabular}




\begin{tabular}{|c|c|c|c|c|}
\hline $\begin{array}{l}\text { Harmful } \\
\text { nature of } \\
\text { tobacco } \\
\text { products a }\end{array}$ & $\begin{array}{l}\text { The harmful } \\
\text { and addictive } \\
\text { nature of } \\
\text { tobacco } \\
\text { products bring } \\
\text { more harms } \\
\text { than good to the } \\
\text { society. }\end{array}$ & $\begin{array}{l}\text { Tobacco } \\
\text { products should } \\
\text { not be marketed } \\
\text { because they are } \\
\text { harmful to the } \\
\text { society. }\end{array}$ & --- & --- \\
\hline $\begin{array}{l}\text { Tobacco } \\
\text { marketing } \\
\text { targeting } \\
\text { vulnerable } \\
\text { groups }\end{array}$ & --- & $\begin{array}{l}\text { Neglecting the } \\
\text { well-being of } \\
\text { children, } \\
\text { teenagers and } \\
\text { people with } \\
\text { low- } \\
\text { socioeconomic } \\
\text { status by selling } \\
\text { harmful } \\
\text { products. }\end{array}$ & $\begin{array}{l}\text { Enhancing } \\
\text { tobacco brand } \\
\text { image amongst } \\
\text { children, } \\
\text { teenagers and } \\
\text { people with low- } \\
\text { socioeconomic } \\
\text { status by } \\
\text { developing } \\
\text { attractive } \\
\text { marketing } \\
\text { activities and } \\
\text { messages for } \\
\text { these target } \\
\text { groups. }\end{array}$ & $\begin{array}{l}\text { Tobacco } \\
\text { marketing } \\
\text { activities do not } \\
\text { prioritise the } \\
\text { well-being of the } \\
\text { vulnerable } \\
\text { groups. }\end{array}$ \\
\hline $\begin{array}{l}\text { Deception in } \\
\text { tobacco }\end{array}$ & --- & $\begin{array}{l}\text { Marketing } \\
\text { harmful }\end{array}$ & $\begin{array}{l}\text { Intentionally } \\
\text { deceiving the }\end{array}$ & \\
\hline
\end{tabular}




\begin{tabular}{|c|c|c|c|c|}
\hline $\begin{array}{l}\text { marketing } \\
\text { messages }\end{array}$ & & $\begin{array}{l}\text { products to the } \\
\text { society. } \\
\text { Glamourising } \\
\text { the temporary } \\
\text { pleasure } \\
\text { customers get } \\
\text { from smoking } \\
\text { but saying } \\
\text { nothing about } \\
\text { the products } \\
\text { well-known } \\
\text { danger to health. }\end{array}$ & $\begin{array}{l}\text { public about the } \\
\text { danger of } \\
\text { smoking by using } \\
\text { attractive tobacco } \\
\text { advertising } \\
\text { themes. }\end{array}$ & --- \\
\hline $\begin{array}{l}\text { Intention } \\
\text { and integrity } \\
\text { of tobacco } \\
\text { marketers }\end{array}$ & --- & --- & $\begin{array}{l}\text { Masking the } \\
\text { distribution of } \\
\text { their products and } \\
\text { enhancing their } \\
\text { image in the } \\
\text { society by } \\
\text { conducting CSR } \\
\text { activities, } \\
\text { offering } \\
\text { scholarships and } \\
\text { sponsoring } \\
\text { events. }\end{array}$ & --- \\
\hline
\end{tabular}




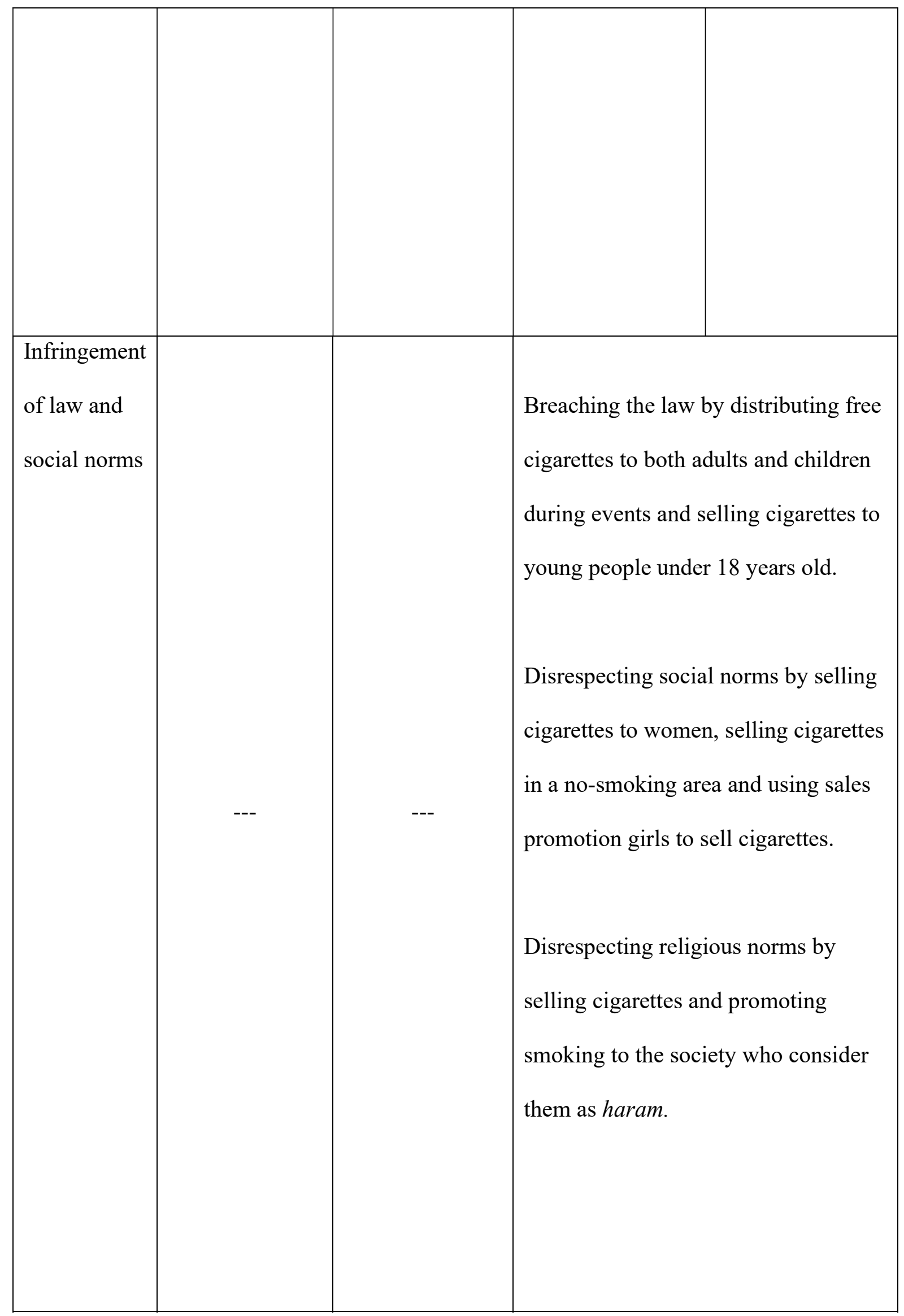




\section{Conclusions}

Adopting a symbiotic ethical approach, this study contributes to the existing body of marketing ethics literature by presenting empirical evidence of the Indonesian public evaluation of tobacco marketing through the theoretical lens of normative ethics, namely utilitarianism, deontology, virtue ethics and contractarianism. Furthermore, the context of this study is unique as it focuses on a country with one of the highest number of smokers in the world but adopts very lenient tobacco control policies.

The findings illustrate six main themes that represent the Indonesian public perception of tobacco marketing ethics, namely economic contribution of the tobacco industry, harmful nature of tobacco products, tobacco marketing targeting vulnerable groups, deception in tobacco marketing messages, intention and integrity of tobacco marketers and infringement of law and social norms. The themes portray the participants' awareness about the ethical implications of tobacco marketing practices in Indonesia. They also illustrate that tobacco marketing practices in Indonesia are against the utilitarianism, deontology, virtue ethics and contractarianism principles.

Utilitarianism perspective was embedded in the participant evaluation about the economic contribution of tobacco companies. Whilst the participants recognised the employment and economic contribution of the tobacco industry, they also implied that the parties who benefited the most from this industry were the tobacco companies, not the society.

The harmful and addictive nature of tobacco products was the participants' main reference in evaluating the ethics of tobacco marketing. As marketing harmful products was against the 
principles of deontology and virtue ethics, it is suggested that to protect the society, tobacco marketing activities in Indonesia must be completely banned.

Both deontology, virtue ethics and contractarianism exist in participant unfavourable evaluation of tobacco marketing activities that directly and indirectly target the vulnerable groups of children, teenagers and people with low-sociodemographic status. Actions must be taken by the regulators, the tobacco industry and society to protect these vulnerable groups and exclude them from direct and indirect target market of tobacco marketing activities.

Deceptive tobacco advertisements that covered up the danger of smoking were perceived by the participants to be unethical and resulted in their distrust towards the companies' messages. The participant evaluation also illustrated how deception in cigarette advertisements was not aligned with deontology and virtue ethics. Therefore, regulators and tobacco companies must stop presenting a misleading image about smoking and provide more transparent information about the risk of smoking.

Most participants questioned the intention of tobacco companies in conducting their marketing activities, especially through their CSR and sponsorship activities. They believed that the main purpose of conducting these activities was to gain public sympathy as well as selling their harmful products. Therefore, it can be concluded that the intention of tobacco marketers was likely to be unvirtuous. In line with the WHO's suggestion, the Indonesian government must completely ban tobacco companies' sponsorship and CSR activities as they become a marketing vehicle to build its popularity and positive image among the society. 
The participants had witnessed various tobacco marketing activities which were against the law and social norms. These actions beg the question on the moral character and integrity of tobacco companies. The findings indicate that tobacco marketing activities did not reflect responsible actions and did not have the best of intentions for the society, and therefore, not aligned with the principle of contractarianism and virtue ethics. The theme indicates that tougher regulations and penalties must be put in place to protect the society and diminish the aggressiveness of tobacco marketing activities.

\section{Policy implications}

The research findings were disseminated through a public engagement event in Yogyakarta in 2017. The event was attended by 48 key stakeholders including: government health and education departments, anti-tobacco activists, public order enforcers, medical doctors, academics and media. A key group of attendees were representing the Sleman Public Health Office (SPHO), Yogyakarta. The Sleman regency has an area of 575 square kilometres and a population of 850,176. SPHO develops and implements the government's health initiative in the regency.

The information and insight provided by this research was instrumental to inform the development of a new policy for No Smoking Area in education institutions, public transport, health care services, playgrounds, houses of worship, workplace and public places in Sleman. The research findings were utilised in a new mandatory monitoring process, which commenced in March 2018. Informed by the findings, the initiative committee agreed that tobacco advertisements and sponsorship in the areas mentioned above must be banned because, as outlined in this study, they were against normative ethics. The ban of tobacco distribution, advertising and sponsorship were included as three of the primary indicators in 41 
the No-Smoking monitoring instrument. In 2020 almost 2,000 institutions in Sleman have participated in this No Smoking Area initiative.

The insight gained from the public engagement has resulted in the SPHO's support in the 'Child Friendly Regency' initiative. To support the initiative, on 16 April 2019, the Regent of Sleman published an instruction on 'Free from Tobacco Advertisement in No Smoking Area'. The instruction was addressed to all local government leaders, village heads and school headmasters in Sleman to supervise and control that areas within the $0.5 \mathrm{~km}$ radius of the designated No Smoking Area must be free from tobacco advertisements. SPHO also reported that the insight gained from the research resulted in the inclusion of tobacco marketing education in their smoking intervention activities and socialisation and advocacy of No Smoking Area. These activities were delivered at education institutions, local government offices, health promotion trainings, community health centres and other institutions in Sleman.

\section{Limitations and future research}

All efforts have been taken to ensure rigorous data collection and analysis. However, geographically the sample was recruited within one of the provinces in Indonesia. Therefore, future research may investigate sample from more affluent provinces to enable a comprehensive comparison study. Future research may also focus on other controversial products or phenomenon, such as drugs or political campaigns. As children and teenagers are central in the findings, future research may investigate their ethical evaluation of tobacco marketing. The results can be used to develop an intervention that empower them to be more resilient of the unfavourable aspects of cigarette consumption and marketing. 


\section{References}

Arli, D., Rundle-Thiele, S. and Lasmono, H. (2015), “Consumers' evaluation toward tobacco companies: Implications for social marketing”, Marketing Intelligence \& Planning, Vol. 33 No. 3, pp. 276-291.

Bay, M. (2018), “Social Media Ethics: A Rawlsian Approach to Hypertargeting and Psychometrics in Political and Commercial Campaigns", ACM Transactions on Social Computing, Vol. 1 No. 4, pp. 1-14.

Bentham, J. (1789), An Introduction to the Principles of Morals and Legislation, Clarendon, Oxford.

Bialous, S.A. and Eijk, Y. van der. (2020), "How Should Global Tobacco Control Efforts Be Prioritized to Protect Children in Resource-Poor Regions?", AMA Journal of Ethics, American Medical Association, Vol. 22 No. 2, pp. E135-146.

Boseley, S., Collyns, D., Lamb, K. and Dhillon, A. (2018), "How children around the world are exposed to cigarette advertising", The Guardian, available at: https://www.theguardian.com/world/2018/mar/09/how-children-around-the-world-areexposed-to-cigarette-advertising (accessed 31 March 2020).

Brand, V. (2009), "Empirical business ethics research and paradigm analysis”, Journal of Business Ethics, Vol. 86 No. 4, pp. 429-449.

Brand, V. and Slater, A. (2003), "Using a qualitative approach to gain insights into the business ethics experiences of Australian managers in China”, Journal of Business Ethics, Vol. 45 No. 3, pp. 167-182.

Braverman, M.T. and Aarø, L.E. (2004), “Adolescent smoking and exposure to tobacco marketing under a tobacco advertising ban: findings from 2 Norwegian national samples.", American Journal of Public Health, American Public Health Association, Vol. 94 No. 7, pp. 1230-8. 
Chakrabarty, S. and Bass, A.E. (2015), “Comparing virtue, deontological ethics-based corporate social responsibility: Mitigating microfinance risk in institutional voids", Journal of Business Ethics, Vol. 126 No. 3, pp. 487-512.

Chamim, M., Dhyatmika, W., Gaban, F., Lamuri, F. and Hamzah, A. (2011), A Giant Pack of Lies: Bongkah Raksasa Kebohongan - Menyorot Kedigdayaan Industry Rokok Di Indonesia [A Giant Pack of Lies: A Giant Pack of Lies - Evaluating the Strength of Cigarette Industry in Indonesia], Koji Communications Tempo Institute, Jakarta.

Chonko, L.B. and Hunt, S.D. (2000), "Ethics and marketing management: A retrospective and prospective commentary", Journal of Business Research, Vol. 50 No. 3, pp. 235244.

Chun, R. (2019), “How Virtuous Global Firms Say They Are: A Content Analysis of Ethical Values", Journal of Business Ethics, Springer, Vol. 155 No. 1, pp. 57-73.

Clarke, V. and Braun, V. (2016), "Thematic analysis”, in Lyons, E. and Coyle, A. (Eds.), Analysing Qualitative Data in Psychology, 2nd ed., Sage Publications, London, pp. 84 102.

Cooper, C. (2015), “Tobacco companies file lawsuits against UK Government over plain packaging laws | The Independent", Independent, available at: https://www.independent.co.uk/life-style/health-and-families/health-news/tobaccocompanies-file-lawsuits-against-uk-government-over-plain-packaging-laws10270874.html (accessed 4 October 2018).

Coulter, R.H. and Zaltman, G. (1994), "Using the Zaltman Metaphor Elicitation Technique to understand brand images", in Allen, C.T. and John, D.R. (Eds.), Advances in Consumer Research Volume 21, Association for Consumer Research, Provo, UT, pp. 501-507.

Crane, A. (1999), “Are you ethical ? Please tick yes or no on researching ethics in business organizations", Journal of Business Ethics, Vol. 20, pp. 237-248. 
Delpo, M.C. (1999), “Tobacco abroad: Legal and ethical implications of marketing dangerous United States products overseas”, Business and Society Review, Vol. 104 No. 2, pp. 147-162.

Dewhirst, T., Lee, W.B., Fong, G.T. and Ling, P.M. (2016), "Exporting an inherently harmful product: The marketing of Virginia Slims cigarettes in the United States, Japan, and Korea”, Journal of Business Ethics, Springer Netherlands, Vol. 139 No. 1, pp. 161-181.

Dunfee, T.W., Smith, N.C. and Ross, W.T. (1999), "Social contracts and marketing ethics", Journal of Marketing, Vol. 63 No. 3, pp. 14-32.

Ferrell, O.C., Fraedrich, J. and Ferrell, L. (2015), Business Ethics: Ethical Decision Making and Cases, 10th ed., Cengage Learning, Stamford, CT.

Forsyth, S.R., Kennedy, C. and Malone, R.E. (2013), “The effect of the internet on teen and young adult tobacco use: a literature review.", Journal of Pediatric Health Care : Official Publication of National Association of Pediatric Nurse Associates \& Practitioners, Elsevier Ltd, Vol. 27 No. 5, pp. 367-76.

Frith, L. (2012), “Symbiotic Empirical Ethics: A Practical Methodology”, Bioethics, Vol. 26 No. 4, pp. 198-206.

Garcia-Ruiz, P. and Rodriguez-Lluesma, C. (2014), "Consumption practices: A virtue ethics approach", Business Ethics Quarterly, Vol. 24 No. 4, pp. 509-531.

Gaus, G. (2011), The Order of Public Reason: A Theory of Freedom and Morality in a Diverse and Bounded World, Cambridge University Press, Cambridge.

Glenza, J. (2017), “Tobacco companies interfere with health regulations, WHO reports”, The Guardian, available at: https://www.theguardian.com/world/2017/jul/19/tobaccoindustry-government-policy-interference-regulations (accessed 4 October 2018).

Guest, G., Namey, E. and McKenna, K. (2017), “How Many Focus Groups Are Enough? Building an Evidence Base for Nonprobability Sample Sizes”, Field Methods, SAGE 
PublicationsSage CA: Los Angeles, CA, Vol. 29 No. 1, pp. 3-22.

Gunawan, A. (2018), "Ini Kekuatan Industri Rokok RI yang Sulit Dikalahkan [This is the power of tobacco industry in the Republic Indonesia which is difficult to be defeated]", CNBC Indonesia, available at: https://www.cnbcindonesia.com/news/201811042046334-40511/ini-kekuatan-industri-rokok-ri-yang-sulit-dikalahkan/1 (accessed 4 March 2020).

Gustafson, A. (2013), "In defense of a utilitarian business ethic", Business and Society Review, Vol. 3, pp. 325-360.

Hackley, C., Tiwsakul, R. a. and Preuss, L. (2008), “An ethical evaluation of product placement - a deceptive practice ?”, Business Ethics: A European Review, Vol. 17 No. 2, pp. 109-120.

Halai, N. (2007), "Making use of bilingual interview data: Some experiences from the field", The Qualitative Report, Vol. 12 No. September, pp. 344-355.

Harper, D. (2002), “Talking about pictures: A case for photo elicitation”, Visual Studies, Vol. 17 No. 1, pp. 13-26.

Hawker, S. and Kerr, C. (2016), "Doing grounded theory”, Analysing Qualitative Data in Psychology, Sage Publications, London, pp. 147-159.

Henriksen, L. (2012), “Comprehensive tobacco marketing restrictions: promotion, packaging, price and place.”, Tobacco Control, NIH Public Access, Vol. 21 No. 2, pp. 147-53.

Hiller, A.J. (2010), “Challenges in researching consumer ethics: A methodological experiment”, Qualitative Market Research: An International Journal, Vol. 13 No. 3, pp. $236-252$.

Hirschmann, R. (2020), “Tobacco industry in Indonesia - Statistics \& Facts”, Statista, available at: https://www.statista.com/topics/5728/tobacco-industry-in-indonesia/ (accessed 30 March 2020). 
Hosmer, L.T. (1994), "Strategic planning as if ethics mattered”, Strategic Management Journal, Vol. 15 No. S2, pp. 17-34.

Jefriando, M. (2019), “Indonesia finance minister defends plan to raise cigarette prices Reuters", Reuters, available at: https://www.reuters.com/article/us-indonesiatobacco/indonesia-finance-minister-defends-plan-to-raise-cigarette-pricesidUSKBN1W11OG (accessed 30 March 2020).

Krueger, R.A. and Casey, M.A. (2000), Focus Groups: A Practical Guide for Applied Research, Sage Publications, Thousand Oaks, CA.

Laczniak, G.R. and Murphy, P.E. (2006), "Normative Perspectives for Ethical and Socially Responsible Marketing”, Journal of Macromarketing, Vol. 26 No. 2, pp. 154-177. Laczniak, G.R. and Murphy, P.E. (2019), “The role of normative marketing ethics”, Journal of Business Research, Elsevier, Vol. 95 No. June 2018, pp. 401-407.

Lambert, S.D. and Loiselle, C.G. (2008), “Combining individual interviews and focus groups to enhance data richness", Journal of Advanced Nursing, Vol. 62 No. 2, pp. 228-237.

Levine, L. (2019), “Digital Trust and Cooperation with an Integrative Digital Social Contract”, Journal of Business Ethics, Springer Netherlands, Vol. 160 No. 2, pp. 393407.

Lindorff, M., Jonson, E.P. and McGuire, L. (2012), "Strategic corporate social responsibility in controversial industry Sectors: The social value of harm minimisation", Journal of Business Ethics, Vol. 110 No. 4, pp. 457-467.

Luetge, C., Armbrüster, T. and Müller, J. (2016), “Order Ethics: Bridging the Gap Between Contractarianism and Business Ethics", Journal of Business Ethics, Vol. 136 No. 4, pp. 687-697.

Martin, A., Iles, A. and Rosen, C. (2016), “Applying utilitarianism and deontology in managing bisphenol-a risks in the United States", HYLE - International Journal for 
Philosophy of Chemistry, Vol. 22 No. 1, pp. 79-103.

Michel, L. (1999), “Combining focus groups and interviews: Telling how it is; telling how it feels", in Rosaline S. Barbour and Jenny Kitzinger (Eds.), Developing Focus Group Research, Sage Publications, London, pp. 36-46.

Mill, J.S. (1863), Utilitarianism, Savils and Edwards Printers, London.

Morgan, D.L. (1997), Focus Groups as Qualitative Research: Planning and Research Design for Focus Groups, 2nd ed., Sage Publications, Thousand Oaks, CA.

Morton, A. and Greenland, S.J. (2018), “Tobacco CSR and the Ethics Game Paradox: A Qualitative Approach for Evaluating Tobacco Brand Name Strategy Following Plain Packaging”, Springer, Singapore, pp. 179-192.

Murphy, P.E. (1999), “Character and virtue ethics in international marketing: An agenda for managers, researchers and educators", Journal of Business Ethics, Vol. 18 No. 1, pp. 107-124.

Murphy, P.E., Laczniak, G.R. and Harris, F. (2017), Ethics in Marketing: International Cases and Perspectives, 2nd ed., Routledge, London.

National Institute on Drug Abuse [NIDA]. (2020), “Tobacco, Nicotine, and E-Cigarettes”, available at: https://www.drugabuse.gov/node/pdf/1344/tobacco-nicotine-and-ecigarettes (accessed 31 March 2020).

Nicholls, A.J. and Cullen, P. (2004), “The child-parent purchase relationship: 'pester power', human rights and retail ethics", Journal of Retailing and Consumer Services, Vol. 11 No. 2, pp. $75-86$.

Nill, A. and Schibrowsky, J.A. (2007), "Research on marketing ethics : A systematic review of the literature", Journal of Macromarketing, Vol. 27 No. 3, pp. 256-273.

Palazzo, G. and Richter, U. (2005), "CSR business as usual? The case of the tobacco industry", Journal of Business Ethics, Vol. 61 No. 4, pp. 387-401. 
Payne, S. (2016), "Grounded theory", in Lyons, E. and Coyle, A. (Eds.), Analysing Qualitative Data in Psychology, Sage Publications, London, pp. 119-147.

Prabandari, Y.S. and Dewi, A. (2016), "How do Indonesian youth perceive cigarette advertising? A cross-sectional study among Indonesian high school students", Global Health Action, Vol. 9, pp. 1-14.

Rawls, J. (1971), A Theory of Justice, Belknap Press, Cambridge, MA.

Rawls, J. (2001), Justice as Fairness: A Restatement, Harvard University Press, Cambridge, MA.

Reinecke, J., Arnold, D.G. and Palazzo, G. (2016), "Qualitative methods in business ethics, corporate responsibility, and sustainability research", Business Ethics Quarterly, Vol. 26 No. 04, pp. xiii-xxii.

Schlegelmilch, B.B., Öberseder, M. and Magdalena, O. (2009), "Half a century of marketing ethics: Shifting perspectives and emerging trends", Journal of Business Ethics, Vol. 93 No. 1, pp. 1-19.

Schleidgen, S., Jungert, M.C. and Bauer, R.H. (2010), “Mission: Impossible? On empiricalnormative collaboration in ethical reasoning", Ethical Theory and Moral Practice, Vol. 13 No. 1, pp. 59-71.

Shanahan, K.J. and Hopkins, C.D. (2019), "Level of Agreement Between Sales Managers and Salespeople on the Need for Internal Virtue Ethics and a Direct Path from Satisfaction with Manager to Turnover Intent”, Journal of Business Ethics, Springer, Vol. 159 No. 3, pp. 837-848.

Silaen, L. (2019), “Indonesia Rises Cigarette Tax by 23\% in 2020”, The Insider Stories, available at: https://theinsiderstories.com/indonesia-rises-cigarette-tax-by-23-in-2020/ (accessed 7 March 2020).

Solomon, R.C. (1992), Ethics and Excellence: Cooperation and Integrity in Business, Oxford 


\section{University Press, New York, NJ.}

Somerville, I. and Wood, E. (2008), "Business ethics, public relations and corporate social responsibility", in Theaker, A. (Ed.), The Public Relations Handbook, 3rd ed., Routledge, London, pp. 143-160.

Soneji, S., Ambrose, B.K., Lee, W., Sargent, J. and Tanski, S. (2014), “Direct-to-consumer tobacco marketing and its association with tobacco use among adolescents and young adults”, Journal of Adolescent Health, Elsevier Ltd, Vol. 55 No. 2, pp. 209-215.

Spence, L.J. and Rutherfoord, R. (2003), "Small business and empirical perspectives in business ethics: Editorial”, Journal of Business Ethics, Vol. 47 No. 1, pp. 1-5.

Sundaram, D.S. and Mitra, K. (2007), "Ethical evaluation of marketing practices in tobacco industry", International Journal of Business Research, Vol. 7 No. 2.

Terry, G. (2016), "Doing thematic analysis", in Lyons, E. and Coyle, A. (Eds.), Analysing Qualitative Data in Psychology, 2nd ed., Sage Publications, London, pp. 104-118.

Tinkler, P. (2013), Using Photographs in Social and Historical Research, Sage Publications, London.

Tjandra, N. (2018), “'Disneyland for Big Tobacco’: how Indonesia’s lax smoking laws are helping next generation to get hooked", The Conversation, available at: http://theconversation.com/disneyland-for-big-tobacco-how-indonesias-lax-smokinglaws-are-helping-next-generation-to-get-hooked-97489 (accessed 17 August 2019).

Tobacco Atlas. (2020), "Indonesia”, Tobacco Atlas, available at: https://tobaccoatlas.org/country/indonesia/ (accessed 7 March 2020).

Treviño, L.K. and Nelson, K.A. (2011), Managing Business Ethics: Straight Talk about How to Do It Right., John Wiley, New York, NJ.

Truth Initiative. (2018), “Why are 72\% of smokers from lower-income communities?”, Truth Initiative, available at: https://truthinitiative.org/news/why-are-72-percent-smokers- 
lower-income-communities (accessed 24 December 2018).

United Nations. (2020), “United Nations Treaty Collection”, United Nations Treaty Collection, available at:

https://reaties.un.org/pages/ViewDetails.aspx?src=TREATY\&mtdsg_no=IX4\&chapter $=9 \&$ clang=_en $($ accessed 7 March 2020).

VanSandt, C. V, Shepard, J.M. and Zappa, S.M. (2006), “An examination of the relationships between ethical work climate and moral awareness", Journal of Business Ethics, Vol. 68 No. 4, pp. 409-432.

Vermillion, L.J., Lassar, W.M. and Winsor, R.D. (2002), “The Hunt-Vitell general theory of marketing ethics: Can it enhance our understanding of principal-agent relationships in channels of distribution?”, Journal of Business Ethics, Vol. 41 No. 3, pp. 267-285.

Wan, W. (2017), “America's new tobacco crisis: The rich stopped smoking, the poor didn't The Washington Post", The Washington Post, available at: https://www.washingtonpost.com/national/americas-new-tobacco-crisis-the-richstopped-smoking-the-poor-didnt/2017/06/13/a63b42ba-4c8c-11e7-9669250d0b15f83b_story.html?noredirect $=$ on\&utm_term $=.654 \mathrm{~b} 5 \mathrm{df3} 081 \mathrm{e}$ (accessed 24 December 2018).

Weaver, G.R. and Trevino, L.K. (1994), "Normative and empirical business ethics: separation, marriage of convenience, or marriage of necessity?", Business Ethics Quarterly, Vol. 4 No. 2, pp. 129-143.

Williams, O.F. and Murphy, P.E. (1990), “The ethics of virtue: A moral theory for marketing", Journal of Macromarketing, Vol. 10 No. 1, pp. 19-29.

World Bank Group. (2018), "The economics of tobacco taxation and employment in Indonesia", available at: http://documents.worldbank.org/curated/en/313111526648544816/pdf/WP-P154568- 
PUBLIC-WBGIndoEmploymentFINAL.pdf (accessed 31 March 2020).

World Health Organization [WHO]. (2018), "Factsheet 2018 Indonesia”, available at: https://apps.who.int/iris/bitstream/handle/10665/272673/wntd_2018_indonesia_fs.pdf?s equence $=1$ (accessed 4 March 2020).

World Health Organization [WHO]. (2019), "WHO launches new report on global tobacco use trends", World Health Organization [WHO], available at:

https://www.who.int/news-room/detail/19-12-2019-who-launches-new-report-on-globaltobacco-use-trends (accessed 30 March 2020).

World Health Organization [WHO]. (2020), “Tobacco Free Initiative (TFI) - Taxation”, WHO, World Health Organization, available at:

https://www.who.int/tobacco/economics/taxation/en/index1.html (accessed 7 March 2020).

Yoon, Y., Gürhan-Canli, Z. and Schwarz, N. (2006), “The effect of corporate social responsibility (CSR) activities on companies with bad reputations", Journal of Consumer Psychology, Vol. 16 No. 4, pp. 377-390. 